\title{
What works to improve outcomes for Kenya's adolescent girls?
}

Population Council

Follow this and additional works at: https://knowledgecommons.popcouncil.org/departments_sbsr-pgy

Part of the Demography, Population, and Ecology Commons, Family, Life Course, and Society Commons, Gender and Sexuality Commons, and the International Public Health Commons How does access to this work benefit you? Let us know!

\section{Recommended Citation}

What works to improve outcomes for Kenya's adolescent girls? Adolescent Girls Initiative-Kenya fact sheet. Nairobi: Population Council, 2018. 

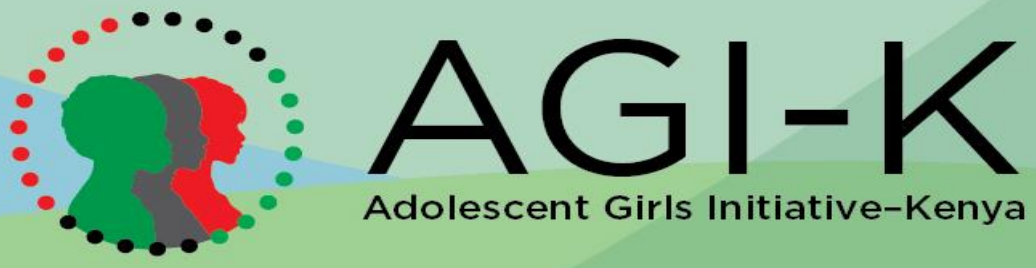

Adolescent Girls Initiative-Kenya

\section{WHAT WORKS TO IMPROVE OUTCOMES FOR KENYA'S ADOLESCENT GIRLS?}

The Adolescent Girls Initiative - Kenya is a study that evaluates the long term impact of a multi-sectoral intervention targeted at adolescent girls aged 11 to 15 years from Kibera and rural Wajir. The intervention consists of four different components: a community based violence prevention program, an education conditional cash transfer (CCT), health focused girls empowerment clubs and wealth creation for girls via financial education and savings (account in urban site, home banks in Wajir).

\section{RESEARCH DESIGN}

A random selection of 6,000 girls were exposed to different components of the intervention, grouped as follows:

1. Violence prevention only (V-only group)

2. Violence prevention + education/Conditional Cash Transfer (VE group)

3. Violence prevention + education/CCT + health clubs (VEH group)

4. Violence prevention + education/CCT + health clubs + wealth creation (VEHW group)

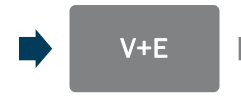

$V+E+H$

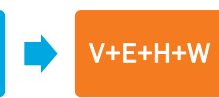

Baseline data was collected in 2015 before the roll out of the intervention began and data was collected again in 2017 at the end of two years of the intervention.

\section{SUMMARY OF KEY FINDINGS}

- A multi-sectoral approach was a costeffective way to create positive change across a range of wellbeing factors for young adolescent girls, including education, health and economic outcomes.

- Education cash transfers worked, and impact varied depending on context.

- In areas where enrollment is close to $100 \%$ such as Kibera, cash transfers improved completion of primary school (from $84 \%$ to $91 \%$ ) and transition to secondary school (from $81 \%$ to $89 \%$ ).

- In Wajir where only $75 \%$ of girls were in school at baseline, cash transfers increased enrollment to $95 \%$ - a huge improvement.

- Cash transfers also encourage good will towards and participation in the health and wealth parts of the program, especially in low-resourced, socially-conservative settings.

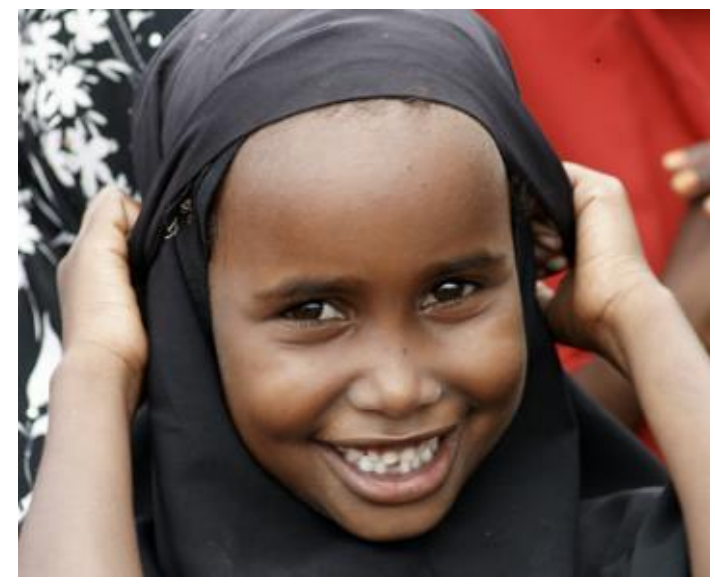


- Participating in girls clubs strengthened impacts on all sectors, including education.

- The results suggest that being active in a girl's empowerment club, which focuses on improving health knowledge, self-efficacy and social safety nets, further improves education outcomes. This makes the investment in the cost of establishing and maintaining the safe spaces platform good value for money.

- In socially-conservative settings, sexual and reproductive health content knowledge showed no change, though the safe spaces platform led to small improvements on gender norms and self-efficacy and allowed for the delivery of the economic strengthening content.

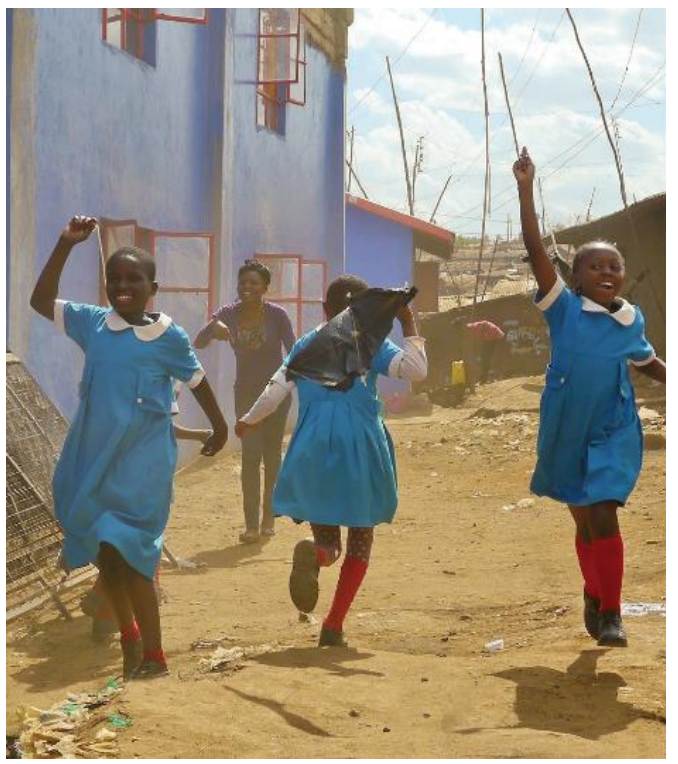

- Financial literacy and savings improved in both sites.

- Girls showed strong increases in their financial literacy and savings behavior, in both frequency and amount.

- It is too early to know if the intervention packages will delay child-bearing; these longer-term results are expected in early 2020.

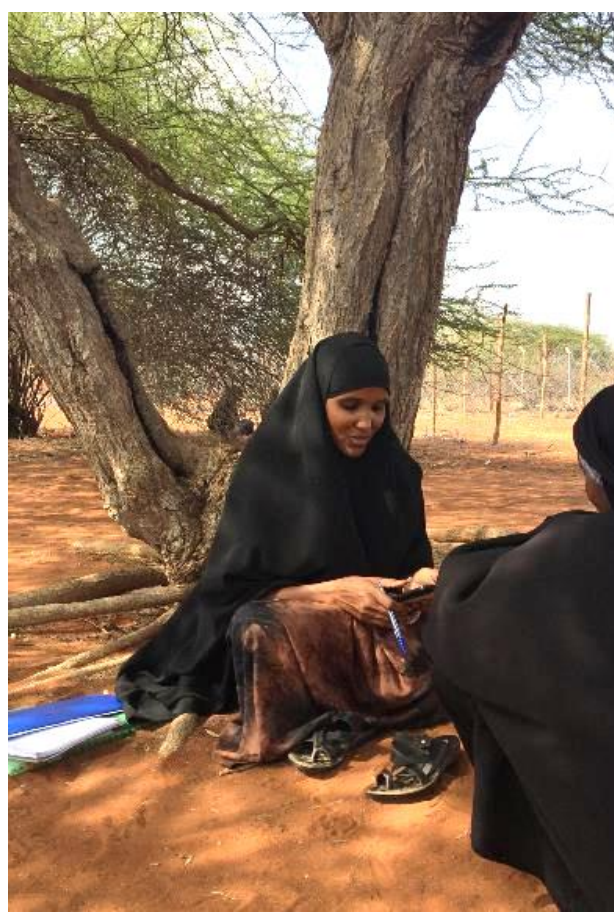

This program is funded by the UK Department for International Development (DFID). The project is implemented by a highly qualified consortium, led by the Population Council in partnership with the African Population and Health Research Center (APHRC) and Itad as research partners, Save the Children in Kenya as the implementing partner in Wajir County, and Plan International-Kenya as the implementing partner in Kibera.

\section{CONTACT INFORMATION}

For more information about AGI-K, call +254-20-2713480

or email info@popcouncil.org

or visit: www.popcouncil.org/research/adolescent-girlsinitiative-action-research-program
Population Council

Avenue 5, $3^{\text {rd }}$ Floor

Rose Avenue

PO Box 17643-00500

Nairobi, Kenya 